\title{
MODEL PEMBELAJARAN PRAKTIK PENGAYAAN MOTOR LISTRIK ARUS SEARAH BERBANTUAN PROGRAM DELPHI
}

\author{
Istanto Wahyu Djatmiko, Sunyoto, Deny Budi Hertanto \\ Jurusan Pendidikan Teknik Elektro, Fakultas Teknik Universitas Negeri Yogyakarta \\ E-mail: istanto_wj@uny.ac.id
}

\begin{abstract}
This study aims to determine the quality of the direct current electric motor enrichment practice learning media utilizing the Delphi program, the effectiveness of the media, and the enrichment practice learning model utilizing the Delphi program. This study was categorized as a research and development. The subjects of the study were 15 students of the Electrical Engineering Department in Engineering Faculty of Yogyakarta State University. The data was analysed descriptively and described in frequency distribution categories. The results of the study were: (1) the quality of the developed materials and the quality of the developed media were categorized as very good and good respectively (2) the effectiveness of the materials was categorized as good (3) the applicable procedure of the developed learning media for the students
\end{abstract}

\section{Keywords: Delphi Program, Direct Current Electric Motor Enrichment Practice}

\begin{abstract}
ABSTRAK
Tujuan penelitian ini untuk mengetahui kualitas produk media pembelajaran praktik pengayaan mesin listrik, terutama motor listrik arus searah berbantuan program Delphi, efektifitas produk, dan model pembelajaran praktik pengayaannya berbantuan program Delphi. Penelitian ini merupakan penelitian pengembangan (research and development). Subyek penelitian adalah mahasiswa Program Studi Pendidikan Teknik Elektro Fakultas Teknik Universitas Negeri Yogyakarta (FT UNY) sebanyak 15 orang. Data penelitian dianalisis dengan deskriptif yang disajikan dalam dalam bentuk distribusi frekuensi kategori. Hasil penelitian diperoleh: (1) kualitas produk media pembelajaran praktik pengayaan motor listrik arus searah dengan aplikasi simulasi program Delphi, yang mencakup isi materi termasuk dalam kategori sangat layak dan kualitas media termasuk dalam kategori layak, (2) efektivitas produk bahan pembelajaran/instruksional untuk praktik pengayaan motor listrik arus searah dengan program Delphi termasuk dalam kategori layak, dan (3) prosedur model pembelajaran praktik pengayaan motor listrik arus searah dengan program Delphi bagi mahasiswa di Program Studi Pendidikan Teknik Elektro FT UNY.
\end{abstract}

\section{Kata Kunci: Praktik Pengayaan Motor Listrik Arus Searah, Program Delphi}

\section{PENDAHULUAN}

Mesin Listrik merupakan salah satu mata kuliah yang tidak dengan mudah dipahami mahasiswa karena banyak pemahaman terhadap konsep yang bersifat abstrak sehingga sulit untuk membayangkannya. Mesin listrik juga merupakan ilmu yang bersifat empiris. Pernyataan-pernyataan dalam mesin listrik perlu didukung dengan hasil-hasil eksperimen untuk dapat mengkonstruksikan pemahaman konsepkonsep berikutnya. Bila konsep-konsep yang bersifat abstrak tersebut dapat dibuat dalam bentuk yang nyata akan dapat memudahkan mahasiswa dalam mempelajarinya. Di sisi lain, mata kuliah mesin listrik akan dapat dengan mudah dipahami bila didukung kegiatan praktik untuk membuktikan konsep-konsep yang telah dipahami oleh mahasiswa.

Perkembangan teknologi komputer dan program aplikasinya yang semakin pesat dapat digunakan untuk meningkatkan kualitas proses pembelajaran, seperti pemanfaatan e-learning, maupun program aplikasi komputer lain dalam bentuk media interaktif yang mampu membangkitkan motivasi belajar mahasiswa. Dengan bantuan program aplikasi komputer tertentu memungkinkan untuk menampilkan konsepkonsep yang abstrak menjadi nyata dalam bentuk visualisasi statis maupun animasi, 
sehingga akan menambah motivasi mahasiswa dalam mempelajari dan menguasainya. Praktik Mesin Listrik sebagai ilmu yang bersifat abstrak, empiris dan matematis memungkinkan dapat memanfaatkan program aplikasi komputer sebagai media pembelajaran sebagai variasi dalam metoda pembelajaran. Usaha mengubah sistem pembeajaran yang bersifat konvensional ke arah pemanfaatan aplikasi teknologi komputer perlu dilakukan guna menciptakan proses pembelajaran yang menarik dan bermakna bagi mahasiswa agar dapat ditingkatkan prestasi dan motivasi belajarnya. Program Delphi merupakan salah satu aplikasi paket program komputer yang dapat digunakan untuk membantu membuat simulasi pengayaan Praktik Mesin Listrik, karena mampu berfungsi sebagai media informasi dalam bentuk teks, grafik, animasi, analisis kuatitatif, dan umpan balik secara langsung sehingga proses belajar mengajar lebih berkualitas dan bermakna.

Berdasarkan permasalahan di atas, penelitian ini dilaksanakan dengan tujuan: (1) menghasilkan produk media pembelajaran praktik pengayaan mesin listrik, terutama motor listrik arus searah berbantuan program Delphi, (2) mengetahui efektifitas produk, dan (3) model pembelajaran praktik pengayaannya berbantuan program Delphi. Dengan demikian,hasil penelitian ini diharapkan dapat memberikan manfaat khususnya bagi dosen dan mahasiswa di Program Studi Pendidikan Teknik Elektro (S1) dan Teknik Elektro (D3), Fakultas Teknik Universitas Negeri Yogyakarta antara lain: (1) sebagai alternatif media pembelajaran praktik pengayaan mesin listrik yang cocok untuk meningkatkan prestasi belajar mahasiswa dalam mata kuliah Mesin Listrik dan Praktik Mesin Listrik, (2) sebagai metode baru dalam pembelajaran mata kuliah Praktik Mesin Listrik dan sebagai variasi metode dalam mengajar (perkuliahan) bagi dosen, dan (3) meningkatkan motivasi belajar mahasiswa dalam mempelajari mata kuliah Praktik Mesin Listrik.

Husni (2004:1) menerangkan bahwa Delphi adalah software buatan Borland yang sangat popular. Delphi merupakan sebuah bahasa pemrograman, yaitu aplikasi untuk membuat aplikasi. Delphi digunakan untuk membangun aplikasi windows, aplikasi grafis, aplikasi visual, bahkan aplikasi jaringan. Delphi dapat membantu untuk membuat berbagai macam aplikasi yang berjalan di sistem operasi windows, mulai dari sebuah program sederhana sampai dengan program yang berbasiskan client/server atau jaringan. Delphi termasuk aplikasi yang dapat digunakan untuk mengolah teks, grafik, angka, database dan aplikasi web. Selain itu, Delphi juga dapat menangani data dalam berbagai format database, misalnya format Ms-Access, SyBase, Oracle, Interbase, FoxPro, Informix, DB2.

Mesin Listrik merupakan mata kuliah yang membahas konversi energi listrik menjadi energi gerakan putar, energi putaran/mekanik menjadi energi listrik, dan pemindahan energi listrik statis dengan prinsip elektromagnetik. Dengan demikian, lingkup materi mesin listrik dapat dikelompokkan menjadi tiga bagian, yaitu: motor listrik, generator, dan transformator. Dalam aplikasi, ketiga bagian tersebut ditentukan oleh jenis sumber listrik yang digunakan/diharapkan dalam pemakaiannya, yaitu: sumber listrik arus searah (direct current-DC), sumber listrik satu fasa maupun tiga fasa (alternating current-AC).

Motor listrik arus searah (DC) adalah suatu mesin listrik yang berfungsi mengubah tenaga listrik arus searah menjadi tenaga gerak atau mekanik yang berupa putaran dari rotor. Mehta (2002:74-75) membagi jenis-jenis motor DC ini menjadi tiga kelompok ditinjau dari belitan penguatannya, yaitu: 1) motor dengan penguat shunt, 2) motor dengan penguat seri, dan 3) motor penguat kompon. Selanjutnya, unjuk kerja dari sebuah motor DC dapat ditentukan melalui kurva karakteristik yang umumnya disebut sebagai karakteristik motor. Theraja (1980: 628) menjelaskan bahwa terdapat tiga karakterisik pada motor DC, yaitu: (1) kurva karakteristik torsi $\left(\mathrm{T}_{\mathrm{a}}\right)$ terhadap arus armatur $\left(\mathrm{I}_{\mathrm{a}}\right)$, yakni $\mathrm{T}_{\mathrm{a}}=f\left(\mathrm{I}_{\mathrm{a}}\right)$, dimana nilai torsi 
sebanding dengan nilai fluksi dan arus jangkar $\left(T_{a} \infty \Phi I_{a}\right),(2)$ karakteristik kecepatan putaran (n) terhadap arus armatur, yakni $\mathrm{n}=f\left(\mathrm{I}_{\mathrm{a}}\right)$, dimana nilai $\mathrm{n}$ sebanding dengan $\mathrm{E}_{\mathrm{b}} / \Phi$ atau ( $\mathrm{n}$ $\left.\infty \mathrm{E}_{\mathrm{b}} / \Phi\right)$, dan (3) kurva karakteristik kecepatan putaran (n) terhadap torsi, yakni $\mathrm{n}=f\left(\mathrm{~T}_{\mathrm{a}}\right)$. Melalui penelitian ini, karakteristik motor DC ini disimulasikan dengan program Delphi.

\section{METODE}

Pendekatan yang digunakan dalam penelitian ini adalah penelitian pengembangan (research and development) (Theraja, 1980) yang menghasilkan produk berupa bahan instruksional untuk keperluan pada mata kuliah Praktik Mesin Listrik, Jurusan Pendidikan Teknik Elektro, FT UNY. Prosedur pengembangan dilakukan dengan pendekatan analysis, design, development, implementation, evaluation (ADDIE). Secara singkat, kegiatan pada setiap kegiatan dapat dijelaskan sebagai berikut: analisis(analysis) terdiri atas beberapa kegiatan, antara lain: (1) melakukan kajian pelaksanaan perkuliahan mata kuliah teori mesin listrik dan mata kuliah praktik yang selama ini telah dilaksanakan, (2) melakukan kajian materi perkuliahan pada mata kuliah Mesin Listrik dan praktik mesin listrik, dan (3) melakukan kajian prosedur pelaksanaan praktik mesin listrik yang selama ini dilaksanakan. Prosedur perencanaan (design) merupakan kegiatan membuat rancangan struktur software aplikasi berdasarkan pertimbangan kajian yang telah dilakukan sebelumnya dengan menggunakan program Delphi dan membuat rancangan labsheet dengan mempertimbangkan pelaksanaan Praktik Mesin Listrik yang selama ini dilaksanakan. Prosedur pengembangan (development) mencakup beberapa kegiatan, antara lain: (1) membuat flowchart pelaksanaan program pengayaan Praktik Mesin Listrik, (2) melakukan pengembangan tampilan, kemudahan akses, dan ketelitian hasil perhitungan secara teori dengan aplikasi program Delphi yang dirancang, (3) merancang dan membuat manual program Praktik Mesin
Listrik dengan program Delphi, (4) melakukan uji kelayakan program aplikasi dan materi praktik pengayaan mesin listrik kepada ahli program dan ahli materi mesin listrik, dan (5) melakukan revisi program aplikasi dan materi praktik pengayaan mesin listrik berdasarkan masukan ahli program dan ahli materi mesin listrik. Prosedur implementasi (implementation) dengan beberapa kegiatan, antara lain: (1) melakukan ujicoba keterbacaan labsheet praktik pengayaan mesin listrik kepada mahasiswa secara terbatas, (2) melakukan revisi labsheet berdasarkan hasil ujicoba keterbacaan, dan (3) melakukan ujicoba produk dalam praktik mesin listrik secara terbatas kepada mahasiswa. Prosedur evaluasi merupakan kegiatan yang terkait dengan penerapan produk akhir dalam pembelajaran terbatas dan melakukan analisis hasil pembelajaran tersebut.

Terdapat tiga sumber data dalam penelitian, yaitu dari: ahli materi mesin listrik, ahli media untuk program Delphi dari Dosen Jurusan Pendidikan Teknik Elektro FT UNY, dan data dari mahasiswa untuk ujicoba produk terbatas dari mahasiswa subyek penelitian sebanyak 15 orang. Alat pengumpul ketiga sumber data digunakan instrumen penelitian berupa angket. Angket untuk ahli materi terdiri dari empat aspek, yaitu lingkup pembelajaran, penyajian informasi, kualitas materi, dan kemanfaatan materi praktik mesin listrik. Angket untuk ahli media terdiri dari dua aspek, yaitu tampilan dan navigasi. Angket untuk mahasiswa terdiri dari tiga aspek, yaitu keterbacaan program, kemudahan penggunaan program, dan lingkup materi praktik mesin listrik. Uji validitas dan reliabilitas angket dilakukan melalui uji terpakai. Adapun validitas angket dilakukan dengan analisis butir Pearson Product Moment, sedangkan reliabilitas dengan Alpha Cronbach. Hasil uji validitas angket ini dapat diketahui nilai $r_{\mathrm{xy}}$ antara 0,30 sampai dengan 0,71 dan nilai koefisien Alpha sebesar 0,75. Selanjutnya, teknik analisis data empirik dilakukan dengan analisis deskriptif. 


\section{HASIL DAN PEMBAHASAN}

Pelaksanaan pembelajaran Praktik Mesin Listrik pada Jurusan Pendidikan Teknik Elektro FT UNY selama ini dilakukan dengan prosedur tertentu sebagaimana ditunjukkan pada Gambar 1(b). Selama ujian perorangan banyak mahasiswa yang gagal. Bagi mahasiswa yang gagal, diberi kesempatan lagi untuk melaksanakan ujian ulang (remidi). Mahasiswa yang berhasil (lulus), mereka direncanakan menempuh program pengayaan. Pada program pengayaan ini materi yang harus dikerjakan mahasiswa adalah

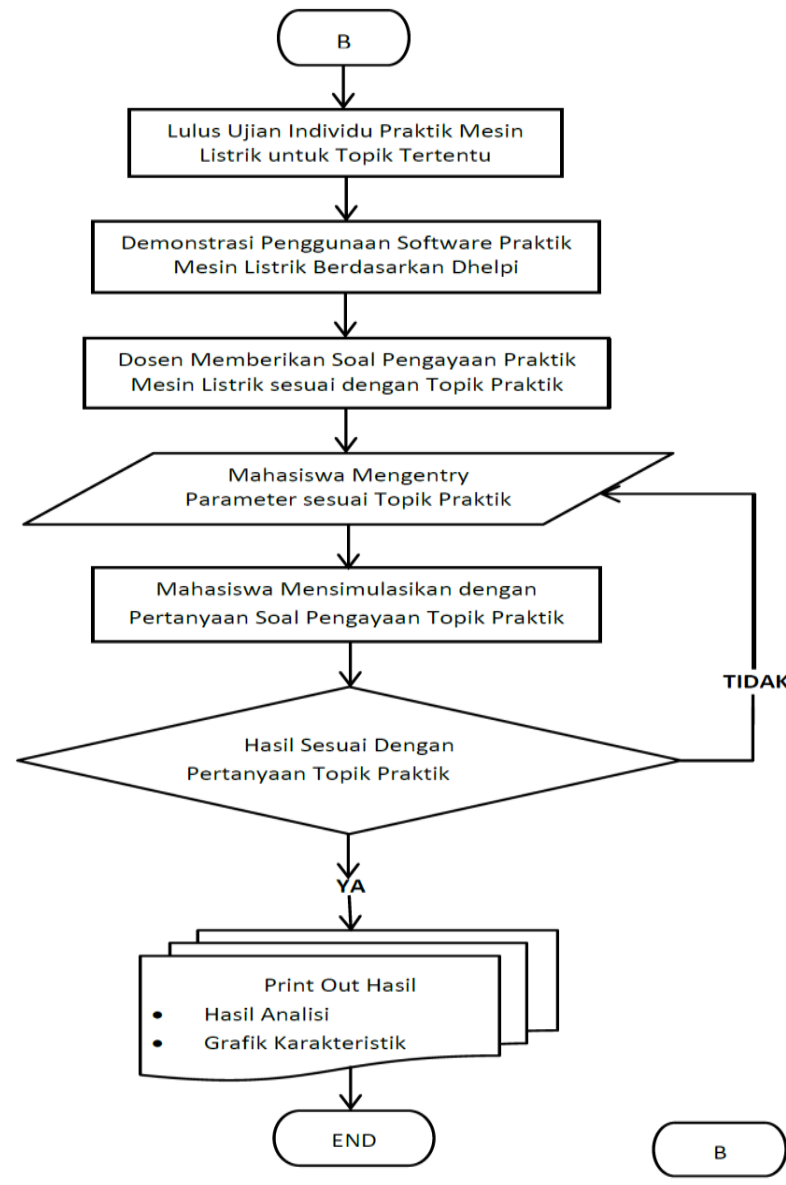

(a) Praktik Pengayaan Mesin Listrik materi praktik diluar materi praktik reguler. Karena unit praktik yang tersedia di laboratorium Mesin Listrik terbatas, maka pengayaan dilakukan dengan menggunakan pola "SIMULASI". Materi simulasi adalah materi yang ada diluar materi praktik reguler. Dengan pengayaan ini diharapkan dapat menambah skill mahasiswa khususnya pada bidang mesinmesin listrik. Desain model praktik pengayaan mesin listrik dengan program Delphi yang dikembangkan dalam penelitian ini diilustrasikan sebagaimana Gambar 1(a).

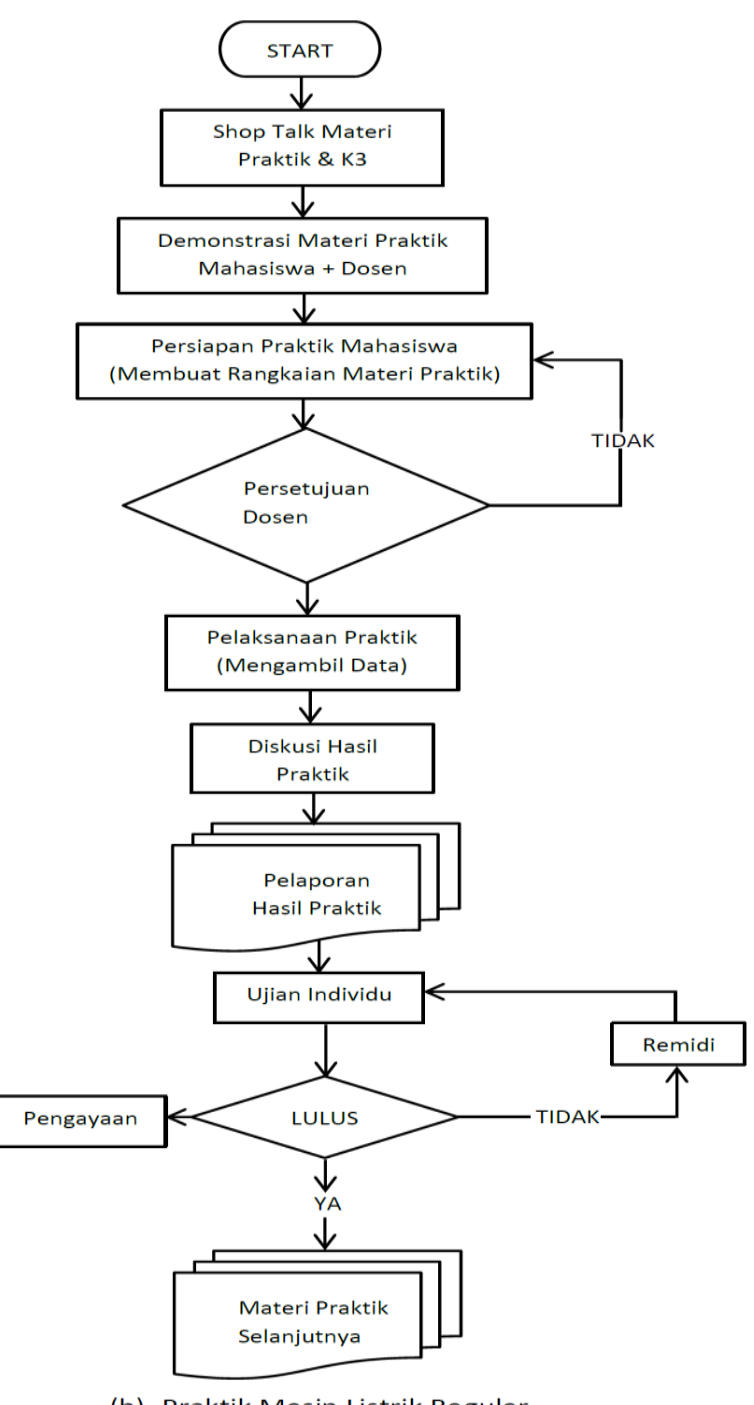

(b) Praktik Mesin Listrik Reguler

\section{Gambar 1. Prosedur Praktik Mesin Listrik}


Hasil penelitian ini memperoleh tiga topik produk praktik pengayaan mesin listrik, yang mencakup analisis teoritik dan karakteristik untuk motor listrik arus searah (DC), motor listrik arus bolak-balik (AC) satu fasa jenis kapasitor permanen (run), dan transformator satu fasa. Karena luasnya cakupan ketiga materi praktik mesin listrik tersebut, makalah ini hanya disajikan pada pengayaan praktik mesin listrik arus searah (DC). Produk model pengayaan praktik mesin listrik dengan pro- gram Delphi menghasilkan berupa perangkat lunak (software) yang diwujudkan dalam bentuk beberapa tampilan, diantaranya adalah: (1) halaman utama, (2) halaman tentang (about), (3) halaman analisis, dan (4) halaman pengayaan.

Desain produk pada tampilan halaman depan terdapat menu utama yang berisi cakupan dari keseluruhan fokus materi praktik pengayaan mesin listrik. Desain menu utama setelah dicompile diperoleh seperti Gambar 2.

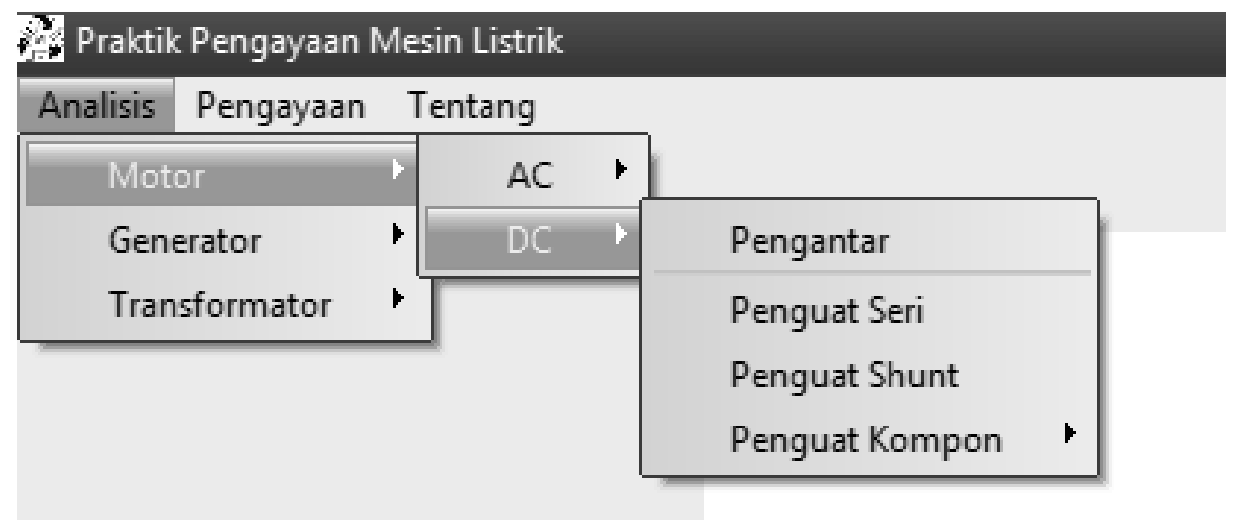

Gambar 2. Tampilan Halaman Utama

Sumber: Istanto Wahyu Djatmiko, Sunyoto, dan Deny Budi Hertanto (2014)

Desain produk pada halaman tentang atau menu about memuat informasi mengenai tujuan pengembangan produk dan fitur-fitur yang ter- sedia pada produk. Desain halaman tentang setelah dicompile diperoleh seperti Gambar 3.

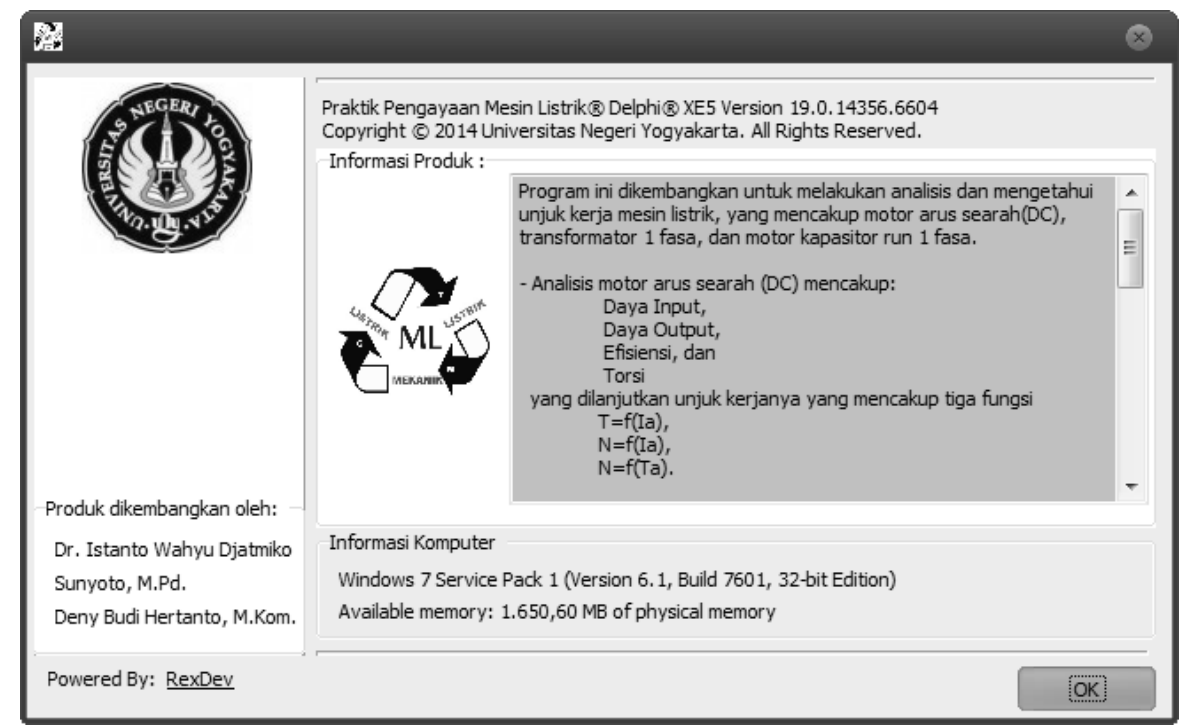

Gambar 3. Tampilan Halaman Tentang

Sumber: Istanto Wahyu Djatmiko, Sunyoto, dan Deny Budi Hertanto (2014) 
Desain produk pada tampilan analisis, memuat tentang analisis dari motor listrik DC, motor listrik AC satu fasa, dan transformator satu fasa. Analisis motor listrik DC terdiri atas analisis terhadap rugi-rugi, torsi, dan efisiensi. Desain halaman analisis setelah dicompile diperoleh seperti Gambar 4.

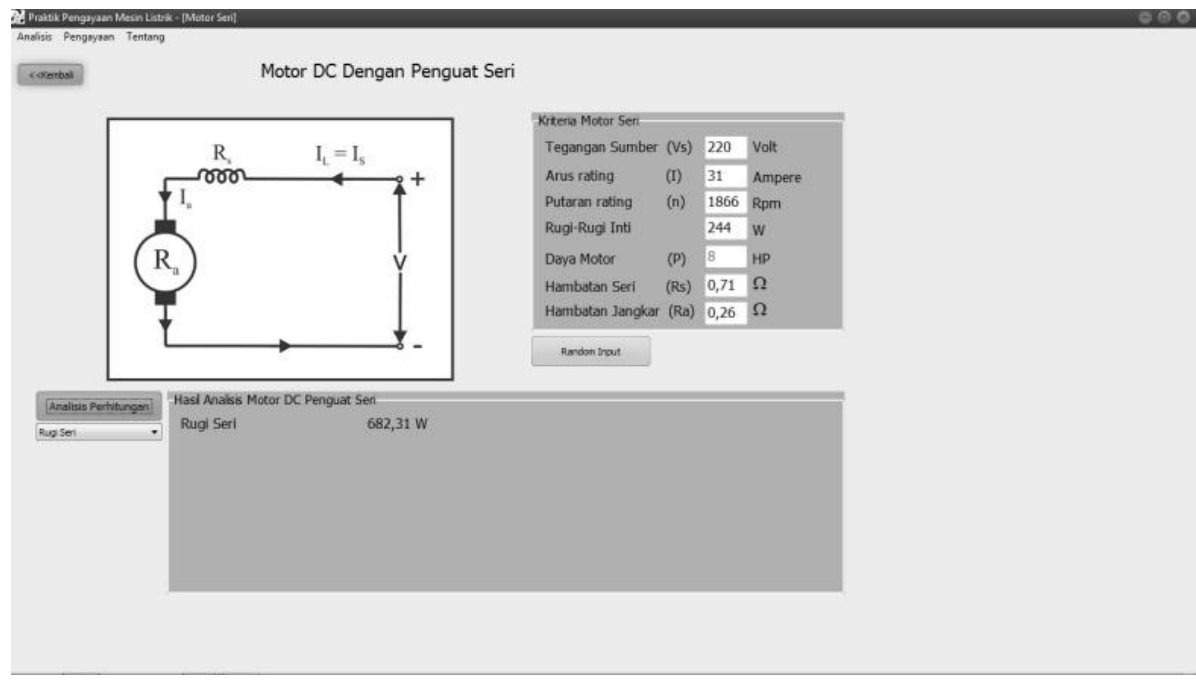

Gambar 4. Tampilan Halaman Analisis

Sumber: Istanto Wahyu Djatmiko, Sunyoto, dan Deny Budi Hertanto (2014)

Selanjutnya, desain produk pada tampilan pengayaan memuat tentang karakteristik dari motor listrik DC, motor listrik AC satu fasa, dan transformator satu fasa. Untuk karakteristik motor listrik DC terdiri dari karaktersitik terhadap $\mathrm{T}=f(\mathrm{Ia}), \mathrm{n}=f(\mathrm{Ta})$, dan $\mathrm{n}=f(\mathrm{Ia})$. Desain halaman pengayaan setelah dicompile diperoleh seperti Gambar 5 .

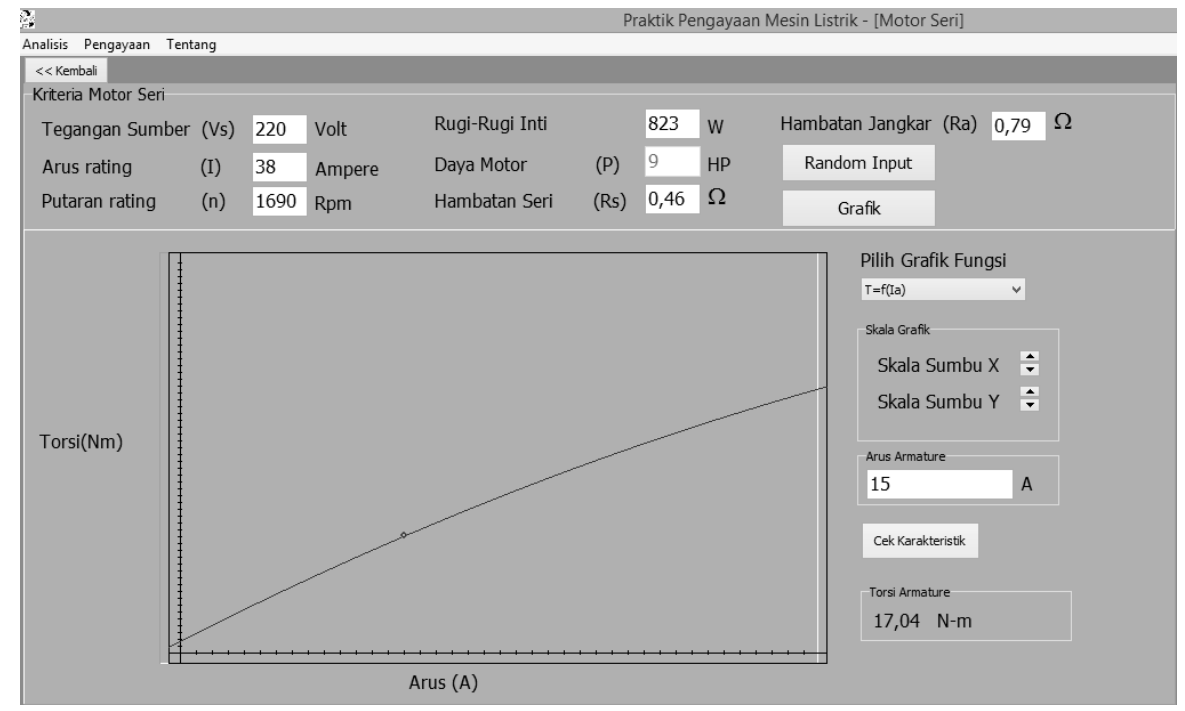

Gambar 5. Tampilan Halaman Pengayaan

Sumber: Istanto Wahyu Djatmiko, Sunyoto, dan Deny Budi Hertanto (2014)

Hasil produk di atas telah melalui uji kelayakan, pada aspek isi materi, media, mau- pun pengguna (user). Hasil uji kelayakan isi materi produk secara keseluruhan termasuk 
dalam kategori sangat layak, dengan rincian ditinjau dari aspek lingkup pembelajaran termasuk kategori sangat layak, aspek penyajian informasi termasuk kategori sangat layak, aspek kualitas materi termasuk kategori layak, dan aspek kebermanfaatan materi termasuk dalam kategori sangat layak.

Hasil uji kelayakan ditinjau dari segi media secara keseluruhan kelayakan program pengayaan praktik mesin listrik ini sebagai media termasuk dalam kategori layak, dengan uraian ditinjau dari aspek tampilan program termasuk kategori sangat layak dan aspek navigasi termasuk dalam kategori layak. Selanjutnya, hasil uji kelayakan oleh pengguna (user) secara keseluruhan kelayakan program pengayaan praktik mesin listrik termasuk dalam kategori layak, yang ditunjukkan dengan indikator aspek keterbacaan program termasuk kategori layak, aspek kemudahan penggunaan program termasuk kategori layak, dan aspek lingkup materi praktik mesin listrik termasuk dalam kategori layak.

Berdasarkan uraian di atas, hasil penelitian dapat dijelaskan bahwa kelayakan kualitas program aplikasi untuk praktik pengayaan mesin listrik, termasuk motor listrik DC, dinilai berdasarkan hasil penilaian yang dilakukan media dan ahli materi. Penilaian kelayakan media ditinjau berdasarkan dua aspek, yaitu aspek tampilan dan aspek navigasi. Aspek tampilan meliputi beberapa indikator, yaitu: ketepatan ukuran tulisan, ketepatan pemilihan jenis huruf, tingkat kualitas gambar, tingkat kualitas grafik, keselarasan penggunaan warna, kemenarikan, dan struktur layout. Selanjutnya, beberapa indikator yang terdapat pada aspek navigasi, diantaranya adalah kejelasan petunjuk navigasi, keandalan pengulangan navigasi, kemudahan dalam pemilihan menu, dan kecepatan akses.

Penilaian kelayakan media dapat dijelaskan berdasarkan data yang diperoleh dari hasil penilaian ahli media yang diperoleh skor rerata total uji kelayakan ahli media sebesar 30,5 dengan rerata skor total maksimal 44 dan rerata skor total minimal sebesar 11, yang berarti skor yang diperoleh termasuk dalam kategori layak berdasarkan pengelompokan kecenderungan data. Selanjutnya, penilaian kelayakan materi ditinjau berdasarkan empat aspek, yaitu: aspek lingkup pembelajaran, penyajian informasi, kualitas materi, dan kelayakan materi. Aspek lingkup pembelajaran meliputi beberapa indikator, yaitu: kesesuaian materi dengan judul, cakupan materi pembelajaran, kesesuaian dengan tujuan pembelajaran, ketepatan muatan materi, dan struktur penyajian materi. Aspek penyajian informasi meliputi beberapa indikator, yaitu: keterbacaan tulisan, ketepatan penggunaan bahasa, kejelasan gambar, kejelasan grafik. Aspek kualitas materi meliputi beberapa indikator, yaitu: ketepatan kompetensi, kebenaran materi, dan sistematika penyampaian materi. Aspek terakhir yang dijadikan penilaian kelayakan kualitas materi, yaitu aspek kemanfaatan materi. Aspek kemanfaatan materi mencakup beberapa indikator, yaitu: kebermanfaatan dalam pembelajaran dan kebermanfaatan dalam keelektroan.

Penilaian kelayakan kualitas materi dapat dijelaskan berdasarkan data yang diperoleh pada hasil penilaian ahli materi yang diperoleh skor rerata total uji kelayakan ahli materi adalah 49,0 dengan rerata skor total maksimal 56 dan rerata skor total minimal adalah 14 , yang bearti skor yang diperoleh termasuk dalam kategori sangat layak. Kualitas program aplikasi praktik pengayaan mesin listrik juga ditentukan melalui tampilan halaman utama, halaman tentang (about), dan halaman pengayaan. tampilan dan fungsi dari halaman-halaman tersebut sangat ditentukan oleh script.

Efektifitas program aplikasi praktik pengayaan mesin listrik dinilai berdasarkan penilaian oleh mahasiswa (subyek penelitian) sebagai pengguna (user) program ini. Penilaian efektifitas media ditinjau berdasarkan tiga aspek, yaitu: aspek keterbacaan program, aspek kemudahan penggunaan program, dan aspek lingkup materi praktik mesin listrik. Aspek keterbacaan program meliputi beberapa indi- 
kator, yaitu: keterbacaan huruf, kesesuaian ukuran huruf dalam program, ketepatan pemilihan jenis huruf dalam program, keserasian warna latar belakang dengan isi, keselarasan warna huruf dengan latar belakang, kejelasan gambar atau grafik, kesesuaian ukuran gambar atau grafik dengan layar, dan kemudahan dalam penggunaan bahasa. Beberapa indikator yang terdapat pada aspek kemudahan penggunaan program, yaitu: cara meng-install program, urutan menu dan sub-menu dalam program, navigasi/perpindahan antar menu dalam program, peng-input-an parameter besaran dalam program, kecepatan respon hasil analisis program, dan cara mengakhiri penggunaan atau menutup program.

Aspek lingkup materi praktik mesin listrik, termasuk motor listrik DC, terdapat beberapa indikator, diantaranya yaitu: penetapan besaran paremeter motor listrik DC yang disimulasikan dengan program, analisis perhitungan parameter motor listrik DC secara manual, analisis perhitungan parameter motor listrik DC dengan menggunakan program simulasi, tingkat akurasi grafik fungsi pada mesin listrik dari program simulasi, dan menyimpulkan hasil tampilan grafik fungsi dengan materi praktik motor listrik DC. Penilaian efektifitas dapat dijelaskan berdasarkan data yang diperoleh dari hasil penilaian mahasiswa (pengguna) yang diperoleh skor rerata total uji kelayakan pengguna sebesar 56,8 dengan rerata skor total maksimal sebesar 76 dan rerata skor total minimal adalah 19 , bearti skor yang diperoleh termasuk dalam kategori sangat layak.

Karena produk perangkat lunak praktik pengayaan mesin listrik memenuhi syarat ditinjau dari segi isi materi, media, maupun analisis dan praktik pengayaan mesin listrik, maka model pembelajaran yang telah dikonsepkan dan alur sebagaimana dijelaskan di muka (Gambar 1) dapat digunakan sebagai acuan dalam pelaksanaan pembelajaran praktik pengayaan mesin listrik, yaitu dengan prosedur sebagai berikut:
1. Bagi mahasiswa yang telah lulus ujian individu praktik mesin listrik pada topik tertentu, dalam hal ini untuk topik motor listrik DC maupun motor listrik AC satu fasa atau transformator satu. Mahasiswa dapat menggunakan produk program aplikasi ini sebagai pengayaan materi/topik yang terkait dengan topik yang telah ditempuh dan dinyatakan lulus.

2. Dosen atau insruktur mendemonstrasikan dahulu software praktik pengayaan mesin listrik ini, yang dimulai dari cara menginstall software sampai dengan pemilihan menu-menu sesuai dengan tujuan yang diharapkan dalam labsheet.

3. Mahasiswa dapat mempraktikkan secara mandiri penggunaan software praktik pengayaan mesin listrik dengan meng-entry parameter yang diperlukan sesuai dengan tujuan praktik pengayaan mesin listrik yang tercantum dalam labsheet.

4. Mahasiswa dapat melihat hasil analisis dan unjuk kerja mesin listrik yang dipraktik dengan cara meng-click sub-sub menu parameter yang diinginkan secara cepat.

5. Mahasiswa dapat membandingkan ketelitian /akurasi hasil analisis secara manual dengan hasil analisis melalui pemanfaatan software ini, baik nilai besaran maupun grafik yang dihasilkan.

\section{SIMPULAN}

Berdasarkan data empirik yang diperoleh dari hasil penelitian dapat disimpulkan sebagai berikut: (1) kualitas produk media pembelajaran praktik pengayaan motor listrik DC dalam bentuk aplikasi simulasi program Delphi, serta motor listrik AC satu fasa, dan transformator satu fasa termasuk dalam kategori sangat layak ditinjau dari segi isi materi dan kualitas media termasuk dalam kategori layak, (2) efektivitas produk bahan instruksional untuk praktik pengayaan motor listrik DC dengan program Delphi termasuk dalam kategori layak, dan (3) dihasilkan prosedur model pembelajaran untuk 
praktik pengayaan motor listrik DC serta motor listrik AC satu fasa dan transformator satu fasa dengan program Delphi bagi mahasiswa di Jurusan Pendidikan Teknik Elektro FT UNY.

\section{DAFTAR RUJUKAN}

Husni. 2004. Pemrograman Database Dengan Delphi. Yogyakarta: Graha Ilmu

Istanto Wahyu Djatmiko, Sunyoto, dan Deny Budi Hertanto.2014.Model Pembelajaran Praktik Pengayaan Mesin Listrik
Berbantuan Program Delphi. Laporan Penelitian. Lembaga Penelitian dan PengabdiankepadaMasyarakat Universitas Negeri Yogyakarta

Mehta, V.K. \& Mehta, R. 2002. Principle of Electrical Machines. India: S. Chand

Theraja, BL. 1980. Electrical Technology. India: Nirja Construction \& Development 